\title{
Physics Learning Using Android Assisted Sm and Physics to Improve Problem-Solving Skill
}

\author{
Delson Albert Gebze ${ }^{1, *}$, Warsono $^{2}$, Nafi' atus Sholihah ${ }^{3}$ \\ ${ }^{123}$ Universitas Negeri Yogyakarta \\ ${ }^{*}$ Corresponding author. Email: delsonalbert.2018@ student.uny.ac.id
}

\begin{abstract}
The outcome of this study are: (1) Finding the characteristic of teaching aids in physics learning using Sm and physics based on local culture suba mish. (2) Creating an android app of the teaching aids of Sm and physics based on local culture. (3) The effectiveness of physics learning based on local culture using sm and physics with android to improve problem-solving skills. The research design used in this study is_one group pretest-postest design and classified as the Research and Development (R\&D) research method that consists of: Define, design, develop, and disseminate steps. This study was held at SMA Negeri 2 Merauke with an empirical test for 250 students, limited test for 32 X MIPA students, and field trials for 64 X MIPA 1 and X MIPA 2 students. The data used in this study are quantitative data obtain from pretest and postest of problem-solving skills and qualitative data obtain from questionnaire. The statistical analysis are using descriptive statistics, $\mathrm{N}$-gain analysis, and MANOVA test with 5\% significance level. The results of this study are: (1) SM and physics can load a topic, image and video of impulse and momentum in physics based on local culture soba mish. (2) Sm and Physics teaching aids based on local culture with android is proper to use according to expert, physics teacher and peer approval. (3) Sm and Physics teaching aids based on local culture with android is eefective to improve students problem solving skills due to (MANOVA) statistical test with result less than 0,05 . There is a significant difference between students in experimental class and control class.
\end{abstract}

Keywords: Sm And Physics, Local Wisdom Suba Mish, Momentum and Impulses, Problem-solving skill.

\section{INTRODUCTION}

The ability to solve problems is one of the demands of the 4.0 Industrial Revolution that must be possessed by every individual. Students in particular are expected to have the ability to solve problems in order to compete in the 4.0 Industrial Revolution. The aim of the curriculum includes problem solving abilities to help students gain new experience in using knowledge and skills to solve problems that are new to them. [1] states that problem solving skills are a major part of learning physics. [2] also says that for a beginner in solving a problem, must pay attention to the nature of problem solving in carrying out a sequence of procedural and systematic operations from one stage to the next. Students who are accustomed to solving problems with synthetic procedures can compete in the real world. Beside students' problem solving abilities, they are also required to master and utilize technology in solving problems in the 4.0 Industrial Revolution.

Technological advances continue to grow and are upgraded to serve the needs of every individual in the 4.0 industrial revolution, students are no exception. Most students have an android smartphone, but it is underutilized in the learning process in the classroom. [3] state the benefits of learning through smartphones are fast and efficient to access study material and create an interactive environment. [4] states that android is a new generation of mobile platform that uses a Linux-based operating system, used on smartphones that includes an operating system, midleware and applications. In addition android has advantages that are complete, open and free. Complete: developers or designers can design, add or change completely when developing an Android platform. Open: open source, developers 
can freely develop Android platforms. Free: Android platform development in the form of an application is free of cost.

Physics learning in school is often applied with phenomena that are outside of the experience of students, so that not a few students consider physics material is difficult to understand. Physics learning usually uses abstract examples so when there are questions and answers or discussion, students are less brave to answer, but when the questions use local wisdom, many of them are dare to answer [5][6]. Learning that is developed based on local wisdom is done because students are accustomed to local wisdom but have not known about the relationship between local wisdom and physics material yet and can foster a sense of love for culture [7][8]. Commonly, the students have already known the Suba Mish, but do not know its relation with physics concept.

Suba mish is one of the traditional hunting tools owned by the Malind Anim Tribe of Merauke Regency, Papua Province. Suba mish or archery is made from basic bamboo culms and the most unique part is the rope is also taken from bamboo which is still green. The way to treat suba mish is quite unique and simple because it uses grated coconut which is smeared throughout the suba mish, this is done to keep the suba mish maintained and not eaten by termites. The uniqueness of Suba Mish can be used in the physics learning process, so that the physics learning that is delivered is embedded in mind and is meaningful to students.

The concept of momentum and impulses contained in suba mish can be poured into the application of SM and Physics or Suba Mish Android Physics which contains material, animation, video and quiz based on suba mish local wisdom. SM and Physics can help students improve their problem solving skills because they utilize local wisdom in explaining the concepts of momentum and impulse.

\section{RESEARCH METHODS}

This research is a developmental study, proposed by [9] with a 4-D model namely; Define, Design, Develop, and Disseminate

\section{1 Research Place and Time}

The study was conducted as SMA Negeri 2 Merauke on January 27 until February 21, 2020.

\section{2 Research Subjects}

Research subjects consisted of empirical test questions, limited product tests, and field tests. The empirical tests consisted of 250 students of class XI and XII. The limited tests consisted of 32 students of class X MIPA 3. Each field test consisted of 32 students of class $\mathrm{X}$ MIPA 1 as the control class and X MIPA 2 as the experiment class.

\section{3 Data Analysis Techniques}

Data analysis techniques in this study as follows:

\subsection{Analysis of Results of Validation of Valuation Instruments}

Analysis of the results of the validation of valuation instruments follows the steps, as follows:

The validation of learning instrument assessment items was analyzed by the V'Aiken test [10]. The V'Aiken equation was used to determine the coefficient of content validity:

$$
\begin{aligned}
V & =\frac{\Sigma s}{n(c-1)} \\
s & =r-l o
\end{aligned}
$$

Table 1. Instrument Criteria

\begin{tabular}{|l|l|}
\hline \multicolumn{1}{|c|}{ Score Range } & \multicolumn{1}{c|}{ Quality Category } \\
\hline $0,8<\mathrm{V} \leq 1$ & Very good \\
\hline $0,6<\mathrm{V} \leq 0,8$ & Good \\
\hline $0,4<\mathrm{V} \leq 0,6$ & Sufficiently \\
\hline $0,2<\mathrm{V} \leq 0,4$ & Less \\
\hline
\end{tabular}

The reliability of scoring instrument items was analyzed using the Borich Test [11]. The scoring percentage scale refers to the equation below:

$$
R=\left(1-\frac{A-B}{A+B}\right) \times 100 \%
$$

The instrument is said to be good if the $\mathrm{R}$ value obtained is $\geq 70 \%$.

\subsection{Analysis of Results of Learning Media Assessment}

Analysis of the results of the learning media assessment follows the equation as follows:

$$
\bar{X}=\frac{\Sigma X}{n}
$$


The total average score data which was originally in the form of a score was changed to a standard value with a reference to changing the score as in table 2 below:
Table 2. Range and Scoring Category

\begin{tabular}{|c|l|}
\hline Score Range & \multicolumn{1}{c|}{ Category } \\
\hline $\mathrm{X}>\mathrm{Mi}+1.80 \mathrm{SBi}$ & $\mathrm{A}=$ Very good \\
\hline $\mathrm{Mi}+0.60 \mathrm{SBi}<\mathrm{X} \leq \mathrm{Mi}+1.80 \mathrm{SBi}$ & $\mathrm{B}=$ Good \\
\hline $\mathrm{Mi}-0.60 \mathrm{SBi}<\mathrm{X} \leq \mathrm{Mi}+0.60 \mathrm{SBi}$ & $\mathrm{C}=$ Sufficiently \\
\hline $\mathrm{Mi}-1.80 \mathrm{SBi}<\mathrm{X} \leq \mathrm{Mi}-0.60 \mathrm{SBi}$ & $\mathrm{D}=$ Less \\
\hline $\mathrm{X} \leq \mathrm{Mi}-1.80 \mathrm{SBi}$ & $\mathrm{E}=$ Very less \\
\hline
\end{tabular}

\subsection{Research Results Analysis}

\subsubsection{Empirical Test Problem}

An empirical test of questions was conducted to determine the number of questions that meet the requirements for use in field trials. Empirical test analysis was performed with the help of the QUEST program .
Problem solving skill test consisted of 8 problem solving items. Improved problem solving skill can be determined by the gain/N-gain value. The following is the equation of the gain value (normalized gain) used:

$$
g=\frac{\text { Postest score }(\%)-\text { Pretest score }(\%)}{\text { Maximum score }- \text { Pretest score }(\%)}
$$

\subsubsection{Problem Solving Skill Test}

Table 3. Gain Index Criteria

\begin{tabular}{|c|c|}
\hline Gain Index & Criteria \\
\hline $\mathrm{g}>0,70$ & High \\
\hline $0,30<\mathrm{g}<0,70$ & Moderate \\
\hline $\mathrm{g} \leq 0,30$ & Low \\
\hline
\end{tabular}

\subsubsection{Statistic Test}

At this stage, it is seen whether the increase in problem solving skills has increased significantly or not. The increase was tested using a parametric statistical test and analyzed using the Two Multivariate Analysis of Variance Group. Sm and Physics learning media as independent variables, while problem solving skill as the dependent variable. Analysis of MANOVA statistical tests used SPSS software version 20.0.

\section{RESULTS AND DISCUSSION}

\subsection{Results of Research Instrument Validation}

\subsubsection{The Validity of Research Instruments}

The validity of the research instrument was carried out to determine the validity of the instruments used which were valid or not, would be tested with V Aiken and estimated reliability using the Borich Test. The research instrument was called reliable when the Borich Test was obtained $\geq 70 \%$. The following are the results of the validity and reliability of each research instrument presented in Table 4.

Table 4. Results of Validity and Reliability of Research Instruments

\begin{tabular}{|c|c|c|c|c|}
\hline Research Instruments & $\begin{array}{l}\text { V Aiken } \\
\text { Coefficient }\end{array}$ & Info. & $\begin{array}{c}\text { Borich } \\
\text { Coefficient } \\
(\%)\end{array}$ & Info. \\
\hline Lesson Plan Assessment Sheet & 1,00 & \multirow{5}{*}{ Valid } & 100 & \multirow{5}{*}{ Reliable } \\
\hline Student Worksheet Assessment Sheet & 1,00 & & 100 & \\
\hline Problem Solving Assessment Sheet & 1,00 & & 100 & \\
\hline Media Assessment Sheet & 1,00 & & 100 & \\
\hline Material Assessment Sheet & 1,00 & & 100 & \\
\hline
\end{tabular}




\section{1,2, Validity of Problem Solving Test}

The results of the validity of the problem solving skill test can be seen in Table 5 .

Table 5. Validity of Problem Solving Skill Tests

\begin{tabular}{|c|c|c|}
\hline Question Item & Validity & Category \\
\hline \multicolumn{3}{|l|}{ Problem Solving } \\
\hline 1 & 0,906 & Very good \\
\hline 2 & 0,875 & Very good \\
\hline 3 & 0,937 & Very good \\
\hline 4 & 0,875 & Very good \\
\hline 5 & 0,875 & Very good \\
\hline 6 & 0,968 & Very good \\
\hline 7 & 0,906 & Very good \\
\hline 8 & 0,937 & Very good \\
\hline
\end{tabular}

Based on the results of the validity of the problem solving skill tests in Table 5, it was found that the problem solving skill test consisting of 8 items with arrange of validity items, was in the range of 0.875 to 0.968 with a very good category. So, it can be concluded that the problem solving test as one of the learning tools is feasible to use.

\subsubsection{SM and Physics Learning Media Assessment}

The assessment of SM and Physics learning media was divided into two aspects namely material aspects and media display aspects. The results of SM and Physics assessment based on Suba Mish local wisdom can be seen in Table 6 .

Table 6. SM and Physics Learning Media Assessment

\begin{tabular}{|c|c|c|c|}
\hline No & Rated aspect & Average Rating & Category \\
\hline \multicolumn{4}{|l|}{ Materi } \\
\hline \multirow[t]{5}{*}{1} & \multirow[t]{5}{*}{ Learning } & 5,00 & Very good \\
\hline & & 4,87 & Very good \\
\hline & & 4,75 & Very good \\
\hline & & 4,75 & Very good \\
\hline & & 4,75 & Very good \\
\hline \multirow[t]{12}{*}{2} & \multirow[t]{12}{*}{ Material } & 4,87 & Very good \\
\hline & & 4,75 & Very good \\
\hline & & 4,75 & Very good \\
\hline & & 4,87 & Very good \\
\hline & & 4,87 & Very good \\
\hline & & 4,75 & Very good \\
\hline & & 4,75 & Very good \\
\hline & & 4,87 & Very good \\
\hline & & 5,00 & Very good \\
\hline & & 4,87 & Very good \\
\hline & & 4,87 & Very good \\
\hline & & 4,75 & Very good \\
\hline \multirow[t]{2}{*}{3} & \multirow[t]{2}{*}{ Audio Visual Display } & 4,87 & Very good \\
\hline & & 4,75 & Very good \\
\hline
\end{tabular}




\begin{tabular}{|c|c|c|c|}
\hline \multirow{2}{*}{} & \multirow{5}{*}{} & 4,87 & Very good \\
\cline { 3 - 3 } & & 4,87 & Very good \\
\cline { 3 - 3 } & & 4,75 & Very good \\
\cline { 3 - 3 } & & 4,87 & Very good \\
\cline { 3 - 4 } & & 5,00 & Very good \\
\cline { 3 - 4 } & 4,87 & Very good \\
\cline { 3 - 4 } & & 4,75 & Very good \\
\cline { 3 - 4 } & & 4,75 & Very good \\
\cline { 3 - 4 } & Software engineering & 4,75 & Very good \\
\hline & & 4,87 & Very good \\
\hline \multirow{2}{*}{ Average Product Rating } & 4,75 & Very good \\
\hline
\end{tabular}

Based on the evaluation of SM and Physics learning media based on Suba Mish local wisdom in Table 6, the average product rating obtained between material and the media assessment is 4.82 with a very good category. So, it can be concluded that the learning media of SM and Physics based on Suba Mish local wisdom developed, is feasible for use in research.

\subsection{Product Test Results}

\subsubsection{Empirical Test}

Empirical tests were given to students who have studied Momentum and Impulse material. Empirical tests were analyzed using QUEST software, where items that were feasible to use were items that were in a fit state with PCM with meansquare infit values in the range of 0.77 to 1.33 . The appropriate items to use are in Figure 1.

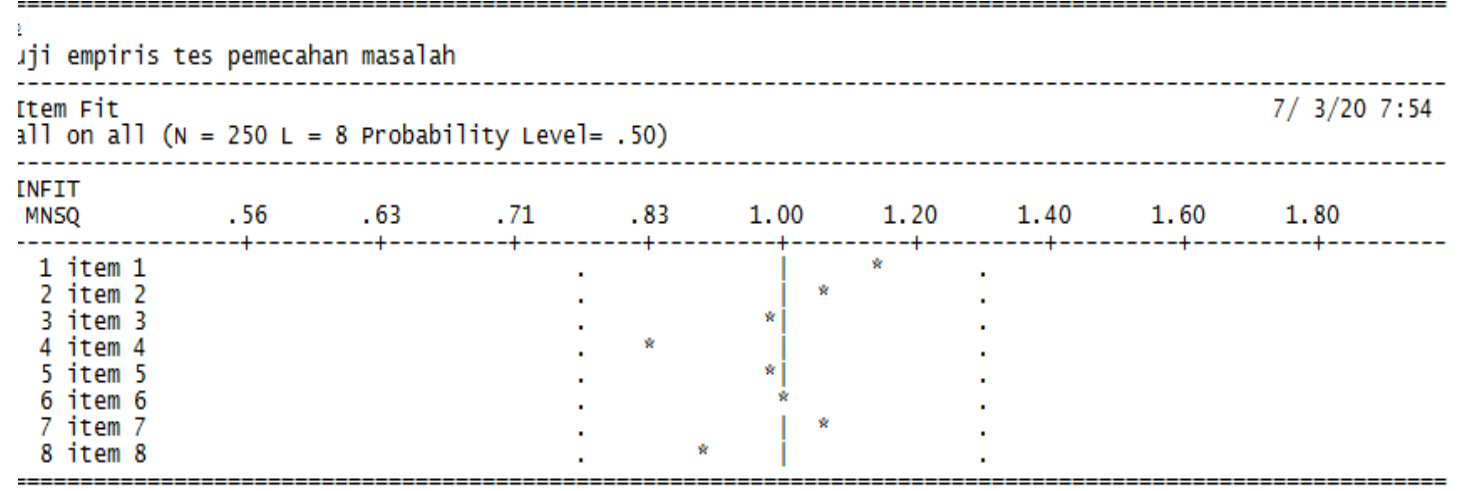

Figure 1. Results of Item Analysis of Problem Solving Test Items

Based on Figure 1, question items that are feasible to use are item 3, 4, 5 and 8 . The results of the summary of case estimate were done to read the reliability test. The results of the interpretation of the reliability value would be compared with the results of the analysis of the KR20 model. Interpretation of the KR-20 reliability values according to Table 7 below:

Table 7. Interpretation of KR-20 Reliability Value

\begin{tabular}{|l|l|}
\hline Reliability Value & Interpretation \\
\hline $0,00-0,20$ & Not reliable \\
\hline$>0,00-0,40$ & Somewhat reliable \\
\hline$>0,40-0,60$ & Sufficiently reliable \\
\hline$>0,60-0,80$ & Reliable \\
\hline
\end{tabular}




\begin{tabular}{|l|c|}
\hline$>0,80-1,00$ & Very reliable \\
\hline
\end{tabular}

The results of the summary of case estimate of 0.80 with a reliable category, this shows the problem solving that is used is reliable.

\begin{tabular}{ll} 
Case Estimates \\
all on al1 $(\mathrm{N}=250 \mathrm{~L}=8$ Probability Leve $=.50)$ \\
\hdashline Summary of case Estimates \\
$==================$ \\
Mean & -.44 \\
SD & 1.36 \\
SD (adjusted) & 1.22 \\
Reliability of estimate & .80
\end{tabular}

Figure 2. Summary of Case Estimate of Problem Solving Test Items

\subsubsection{Product Test}

Product tests were carried out to determine the quality of products developed based on student assessment. The evaluation test was carried out by students who have diverse academic abilities consisting of 32 students. The following results of student assessments are presented in Table 8:

Table 8. Results of Product Valuation

\begin{tabular}{|l|l|c|c|}
\hline No & Rated Aspects & $\begin{array}{c}\text { Scoring } \\
\text { Results }\end{array}$ & Criteria \\
\hline 1 & Material & 4,618 & Very good \\
\hline 2 & Media & 4,607 & Very good \\
\hline Average Scoring & & $\mathbf{4 , 6 1 2}$ & Very good \\
\hline
\end{tabular}

Based on the results of the assessment of the product test, obtained an average scoring of 4.612 with very good criteria. So, it can be concluded that the learning media of SM and Physics based on Suba Mish local wisdom developed is feasible to be used in the next stage, which is the field test stage.

\subsubsection{Field Test}

Field tests were conducted to see the results of problem solving skill improvement after learning with Momentum and Impulse material. Meanwhile, data on the results of problem solving tests are presented in Table 9.

Table 9. Results of Problem Solving Skill Tests

\begin{tabular}{|c|c|c|c|c|c|}
\hline \multirow{2}{*}{ Class } & \multirow{2}{*}{$\begin{array}{l}\text { Number } \\
\text { of Students }\end{array}$} & \multicolumn{2}{|c|}{ Average Problem Solving Skill } & \multirow{2}{*}{$\begin{array}{l}\text { Average } \\
\text { Gain Value }\end{array}$} & \multirow{2}{*}{ Category } \\
\hline & & Pretest & Postest & & \\
\hline Control & \multirow{2}{*}{33} & 17,273 & 62,273 & 0,528 & Moderate \\
\hline Experiment & & 44,848 & 81,364 & 0,606 & Moderate \\
\hline
\end{tabular}

Based on the test results of the problem solving skill test in Table 9, the data obtained in the form of $\mathrm{N}$-gain value of problem solving skill in the control and experimental classes is 0.528 and 0.606 with the moderate category. 


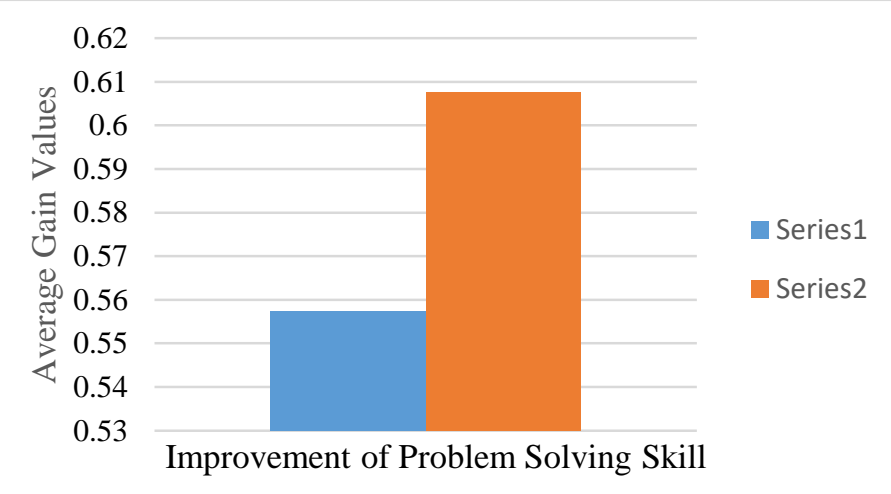

Figure 3. Improvement of Problem Solving Skill

The influence of SM and Physics learning media based on Suba Mish local wisdom with android assisted on Momentum and Impulse material was carried out on problem solving skill, analyzed using the MANOVA test. Requirements before the MANOVA test was carried out first, the data used must meet several test requirements, namely normality and homogeneity tests.

\subsubsection{Normality Test}

Normality test was carried out to find out whether the data coming from experimental and control class values are normally distributed or not. The results of the bivariate normality test are presented in Tabel 10.

Tabel 10. Normality Test Results

\begin{tabular}{|c|c|c|c|c|c|c|c|}
\hline & \multirow[b]{2}{*}{ Clas } & \multicolumn{3}{|c|}{ Kolmogorov-Smirnov2 } & \multicolumn{3}{|c|}{ Shapiro-Wilk } \\
\hline & & Statistic & df & Sig. & Statistic & df & Sig. \\
\hline \multirow[t]{2}{*}{ Pre-Problem Solving } & Experiment & ,137 & 33 & ,118 & ,938 & 33 &, 060 \\
\hline & Control & ,180 & 33 & ,008 & ,947 & 33 & , 109 \\
\hline \multirow[t]{2}{*}{ Pro-Problem Solving } & Experiment & ,165 & 33 & ,023 & ,936 & 33 & 054 \\
\hline & Control & ,166 & 33 & 022 & ,950 & 33 & ,134 \\
\hline
\end{tabular}

Based on the results obtained from normality analysis, the Shapiro-Wilk test was obtained that if the value of $s i g>0.05$ then it is normally distributed. Tabel 10 shows the sig value for the experimental and control class is more than 0.05 so it can be said that the data for both classes are normally distributed.

\subsubsection{Homogeneity Test}

Homogeneity test was performed with Box's M test statistical test with the help of SPSS. Box's M Test data is said to be homogeneous if $s i g>0.05$ with a significance level of 5\%. Box's $\mathrm{M}$ test results are presented in Table 11.

Table 11. Box’s M Test Results

\begin{tabular}{|c|c|c|c|c|c|}
\hline Variable & & & & df2 & sig. \\
\hline Problem Solving & Box's $M$ & F & df1 & d & 0,063 \\
\hline
\end{tabular}

Based on the Box's $M$ test results, it is known that the sig value for the problem solving variable is 0.063 more than 0.05 . So it can be concluded that the two classes between the experimental and control classes have the same variance or both classes were homogeneous.

\subsubsection{Manova Test}

The Manova test was conducted with the aim of finding out whether or not there were differences in the 
improvement of problem solving skill between the two classes. The Manova test used was the Hotteling's
Trace test. The results of the Hotteling's Trace test are presented in Table 12.

Table 12. Results of the Hotteling's Trace Test

\begin{tabular}{|c|r|r|r|c|}
\hline Effect & Variable & sig. & Decision Criteria & Decision \\
\hline $\begin{array}{c}\text { Hotteling's } \\
\text { Trace }\end{array}$ & Problem Solving & 0,000 & sig.< $<0,05$ & $\mathrm{H}_{0}$ is rejected \\
\hline
\end{tabular}

Based on the results of the Hotteling's Trace test, obtained a sig value of 0,000 for the problem solving variable. These results indicate that the sig value is less than 0.05 . So, it can be concluded that there are significant differences in the improvement of problem solving skill between students taught using the SM And Physics learning media based on Suba Mish local wisdom and Suba Mish local wisdom based learning without android assisted.

\section{CONCLUSION}

Based on the results, discussion, and research objectives, it can be concluded that: The characteristics of learning media based on Suba Mish local wisdom android assisted is Sm And Physics. This learning media contains Suba Mish material, pictures and videos of local wisdom associated with the concepts of momentum and impulses that occur in Suba Mish. Learning media developed are feasible based on the results of validity. The SM And Physics learning media is validated by expert lecturers, physics teachers and colleagues by obtaining the average score in the excellent category. The use of Sm and Physics learning media is effective in improving students' problem solving skill based on a sig value of less than 0.05 in the Hotteling's Trace test conducted.

\section{REFERENCES}

[1] Docktor, J. L., \& Mestre, J. P. (2014). Synthesis of Discipline-based Education Research in Physics. Physical Review Special Topics - Physics Education Research, $10 \quad$ (2), $1-58$. https://doi.org/10.1103/PhysRevSTPER.10.020119

[2] Wena, M. (2009). Strategi Pembelajaran Inovatif Kontemporer Suatu Tinjauan Konseptual Operasional. Jakarta: Bumi Aksara.

[3] Khaddage, Ferial, Lattemann, Christoph and Bray, E. (2011). Mobile apps integration for teaching and learning: are teachers ready to re-blend? Proceedings of the Society for Information Technology \& Teacher Education International Conference, AACE, Chesapeake, Va., Pp. 2545 2552.
[4] Istiyanto, J. E. (2013). Pemrograman Smartphone Menggunakan SDK Android dan Hacking Android. Yogyakarta: Graha Ilmu.

[5] Febry Hidayanto, Sriyono, N. N. (2016). Pengembangan Modul Fisika SMA Berbasis Kearifan Lokal Untuk Mengoptimalkan Karakter Peserta Didik. RADIASI: Jurnal Berkala Pendidikan Fisika, 9 (1), 24-29.

[6] Mustika Wati, Sri Hartini, Misbah, R. (2017). Pengembangan Modul Fisika Berintegrasi Kearifan Lokal Hulu Sungai Selatan. Jurnal Inovasi Dan Pembelajaran Fisika, 4 (2), 157-162.

[7] Novi Ratna Dewi, I. A. C. D. (2013). Pengembangan CD Pembelajaran Berbasis Kearifan Lokal Tema Getaran Dan Gelombang Untuk Siswa SMP Kelas VIII. USEJ - Unnes Science Education Journal, $\quad 2 \quad$ (2), 274-281. https://doi.org/10.15294/usej.v2i2.2036

[8] Sholakhudin, N., Sutarto, S., \& Subiki, S. (2016). Paket Sumber Belajar (PSB) Dengan Analisis Foto Kejadian Fisika (AFKF) Berbasis Kearifan Lokal Pada Pembelajaran Fisika Di SMK. Jurnal Pembelajaran Fisika, 5 (3), 253-260.

[9] Thiagarajan, S. Semmel, D.S \& Semmel, M. (1974). Instructional Development for Training of Exceptional Children. Indiana: Indiana University Bloomington.

[10] Aiken, L. R. (1985). Three Coefficients foe Analyzing The Reliability, and Validily of Ratings. Educational and Psychological Measurement.

[11] Borich, G. D. (1994). Observation Skill For Effective Teaching. New York: Mac Millian Publishing Company. 